\title{
ЗАСТОСУВАННЯ ІНФОРМАЦІЙНИХ ТЕХНОЛОГІЙ У ПРОФЕСІЙНІЙ ПІДГОТОВЦІ ФАХІВЦІВ 3 МАРКЕТИНГУ
}

\begin{abstract}
Анотація. Впровадження сучасних методів навчання є важливим напрямком вдосконалення підготовки студентів у сучасному навчальному закладі. У роботі розглянуто необхідність застосування сучасних інформаційних технологій у процесі професійної підготовки майбутніх фахівців з маркетингу. Розглянуто види засобів навчання які функціонують на основі IT. Визначено основні етапи, умови та шляхи фрормування інформаційно-технологічної компетенції майбутніх фрахівців. Визначені унікальні можливості та переваги використання інформаційних технологій у навчальному процесі, що дозволяють підвищити якість підготовки студентів та рівень професійної діяльності. Встановлено важливість вивчення дисциплін із застосуванням Internet-технологій при організації дистанційного навчання. Досліджено особливості реалізації підготовки фахівців з урахуванням шкідливого впливу комп'ютерних технологій на фрізичне та психологічне здоров'я людини.
\end{abstract}

Ключові слова: інформаційні технології, освіта, фрахівці, маркетинг, навчальний заклад, інтерактивні технології, інформаційно-технологічна компетенція.

Yanchuk Tetiana, Buha Nataliia, Krupchatnikova Tetiana Vasyl' Stus Donetsk National University

\section{APPLICATION OF INFORMATION TECHNOLOGIES IN THE TRAINING OF MARKETING PROFESSIONALS}

Summary. The introduction of modern teaching methods is an important way to improve the training of students in a modern educational institution. The potential of modern information technology is much greater, the methods already identified and the ways in which they can be used to enhance cognitive activity. The necessity of application of modern information technologies in the process of professional training of future marketing specialists is considered. The types of learning tools that operate on the basis of IT are considered. An information and software system to support learning is needed. Tools such as text processors, spreadsheets, video editing, graphics editors, services and presentation programs are useful in the preparation of lectures, workshops and laboratory workshops. The use of social media, e-mail and cloud data storage will address organizational issues of usability and speed of access to educational materials. The main stages, conditions and ways of formation of information-technological competence of future specialists are determined. Unique opportunities and advantages of using information technologies in the educational process are identified, which allow improving the quality of students' training and the level of professional activity. The use of computer technology as a teaching tool makes it possible to improve the teaching process, improve its quality and efficiency, and make it possible to find the necessary information quickly. The importance of studying disciplines with the use of Internet-technologies in the organization of distance learning has been established. Distance learning allows extensive use of the best teaching resources; combines high economic efficiency and flexibility of training; expands the possibilities of various forms of education. Peculiarities of realization of training of specialists taking into account harmful influence of computer technologies on physical and psychological health of the person are investigated. The application of information technology in the training of professionals can have a significant learning effect, with a reasonable mix of traditional and IT-based teaching methods.

Keywords: information technologies, education, specialists, marketing, educational institution, interactive technologies, information technology competence.

Постановка проблеми. Інформаційні 1 технології впевнено впроваджуються в усі сфери діяльності, в тому числі й у систему освіти. Використання інформаційних технологій в навчальному процесі є актуальною проблемою сучасної професійної освіти. У сучасних умовах підвищення якості освіти у вищих навчальних закладах нерозривно пов'язане 3 впровадженням інновацій. Головним завданням є створення інноваційного середовища в освітній та науковій діяльності, яке допоможе пристосуватись до мінливих умов українського та міжнародного освітнього простору, за допомогою інтеграції освіти, науки та інноваційної діяльності, співпраці з підприемствами та організаціями, застосування перспективних технологій, які активізують науково-дослідну і освітню діяльність.
Аналіз останніх досліджень та публікацій. Різноманітні аспекти професійної підготовки фахівців е предметом наукових досліджень таких вітчизняних та зарубіжних вчених, як Кобилянська I.М., Савчук О.І., Волков Ю.А., Шарлай А.С., Голуб Т.В., Дядичев В.В., Журавльова Є.А., Пасека М.C., Андреєв B.M., Горшкова Е.Е., Грішних А.А., Ігнатьєв С.А., Терехова М.А., Вахидова К.Л., Тазуева Ж.М. При цьому розглядали питання, пов'язані з розробкою моделі підготовки висококваліфікованого фахівця, визначенням оптимального обсягу та змісту предметів навчання для розширення знань та творчого розвитку студентів, удосконалення умінь застосування наукових знань, враховуючи стан науково-технічного прогресу. Проте, роль застосування інформаційних технологій в процесі формування 
профресійних компетенцій майбутніх фрахівців 3 маркетингу досліджена недостатньо.

Мета статті. Головною метою цієї роботи $є$ дослідження ролі інформаційних технологій у процесі профресійної підготовки фрахівців з маркетингу.

Виклад основного матеріалу. Об'еднання традиційних методів навчання 3 комп'ютерними технологіями сприяе підвищенню успішності студентів, стимулюе розвиток самостійної роботи. Головна мета застосування інформаційних технологій (IT) у профресійній підготовці драхівців отримання студентами знань, умінь і навичок, які необхідні для ефрективної взаємодії з сучасними засобами комп'ютерної техніки та новими індормаційними технологіями в навчальному процесі та майбутній професійній діяльності. Комп'ютерні технології виводять освітній процес на новий рівень розвитку. Застосування IT дозволяє значно заощадити час студента, надати інформацію в інтерактивному вигляді, що сприяе кращому засвоєнню навчальної програми і не тільки [1].

Останнім часом зріс попит на кваліфікованих фрахівців в області маркетингу, які здатні аналізувати діяльність підприемства та на основі цього приймати управлінські рішення. Навчальна програма за даним напрямом має відповідати вимогам часу та відображати її загальні та спещіальні характеристики, вимоги до підготовки студентів, необхідні кадрові, матеріально-технічні, інформаційні, методичні та інші ресурси.

Профресія маркетолога є творчою і вимагає

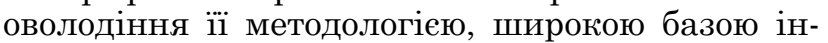
струментарію, тому важливо основні профресійні освітні програми з підготовки фрахівців реалізовувати 3 використанням передових освітніх технологій, в тому числі і інформаційних, що забезпечують вільний доступ в мережу Internet, які передбачають використання навчальних матеріалів в електронному вигляді, мультимедійних засобів та ін.

Засобами профресійної підготовки фрахівців, які фрункціонують на основі інфрормаційних технологій $є$ [2-3]:

- електронні навчально-методичні портали 3 матеріалами з усіх дисциплін, які вивчаються у навчальному закладі, як найважливіша інфраструктурна складова навчального процесу (електронні підручники; програми курсів; лекції, практичні завдання, лабораторні роботи у електронному вигляді; завдання для самостійної роботи; теми рефератів, курсових тощо);

- програмні засоби навчання, призначені для підтримки процесу викладання навчального предмета (курсу), такі як особисті електронні кабінети викладачів та студентів, які забезпечують їх взаємодію у процесі обміну навчальними матеріалами, завданнями для самопідготовки та контроль їх виконання;

- об'єктно-орієнтовані програмні системи, призначені для формування інфрормаційної культури i, зокрема, культури навчальної діяльності;

- навчальне, демонстраційне обладнання спільно з комп'ютером, призначене для самостійного вивчення навчального матеріалу при забезпеченні предметності діяльності, їі практичної спрямованості i, крім того, дозволяе студенту реалізовувати спектр можливостей засобів нових інформаційних технологій (управління реальни- ми об'єктами, введення та редагування текстової та графрічної інфрормаціі);

- системи штучного інтелекту, призначені для організації процесу самонавчання;

- засоби контролю та тестування, що забезпечують гнучкий контроль за рівнем знань учнів, видачу рекомендацій щодо додаткового вивчення необхідних розділів.

Під час навчання фрахівців 3 маркетингу можуть використовуватися наступні інформаційні технології (табл. 1). Сучасний бізнес пред'являе високі вимоги до фрахівців в області маркетингу. Так маркетологи повинні уміти проводити маркетингові дослідження, аналізувати внутрішню та зовнішню інформацію, складати та втілювати у життя маркетингові плани, мати навики роботи 3 маркетинговими програмами. Наведені інформаційні технології дозволяють розширюють доступ до освіти, їх вивчення під час профресійної підготовки у навчальному закладі дозволяе відповідати усім поставленим вимогам. Ефективна підготовка фрахівців з маркетингу полягає у поєднанні теоретичних і практичних завдань, що дозволяе бачити реальну віддачу від програм і мотивує студентів на їх освоєння.

Під час навчального процесу необхідно використовувати якомога більше джерел та матеріалів (наприклад, освітніх сайтів і студентських порталів), які допоможуть зробити навчання більш цікавим і різноманітним. Застосування соціальних мереж, електронної пошти і хмарного сховища даних вирішить організащійні питання щодо зручності та швидкості доступу до навчальних матеріалів. IT для навчання $є$ інтерактивними, якщо реалізуеться можливість вести діалог з учнем або викладачем, що і становить головну особливість методик IT навчання. Ефективним є використання таких інтерактивних технологій, як лекції-бесіди, лекції-дискусії, лекцій з розбором конкретних ситуащій тощо. Ще більш широкий спектр активних та інтерактивних форм навчання фрахівців можна застосувати на практичних заняттях: різні форми ділових ігор, ігрове проєктування, тематичні дискусії, мозкові атаки (штурми), ігрові вправи, кейс-технології та інші [4].

Для контролю знань майбутніх фрахівців 3 маркетингу також можна використовувати активні та інтерактивні фрорми - комп'ютерне тестування; рішення виробничих завдань; case-study. На практичних заняттях важливо активно використовувати технічні засоби - презентації, комп'ютерні навчальні програми, відеофрільми, слайд-лекції, електронні підручники.

Впровадження у навчальну діяльність таких ресурсів як веб-конференції та форуми є також важливим, особливо під час дистанщійного навчання, яке здійснюеться за допомогою Інтернету. Глобальна мережа Internet дозволяе передавати на будь-які відстані інформацію будь-якого виду (наприклад, звукову, графічну, текстову та ін.) й обсягу. Заняття 3 використанням комп'ютерних технологій забезпечують зворотний зв'язок 3 викладачем та іншими учасниками навчального курсу. Вивчення дисциплін із застосуванням Internet-технологій допомагає сорормувати у студентів профресійні компетенції, визначені предметною галуззю, в якій майбутній фрахівець повинен бути добре обізнаний і в якій 
Інформаційні технології навчання у підготовці фахівців з маркетингу

\begin{tabular}{|l|l|}
\hline \multicolumn{1}{|c|}{ Інформаційні технології } & \multicolumn{1}{c|}{ Призначення } \\
\hline Moodle, eLearning 3000, Claroline LMS, ATutor & $\begin{array}{l}\text { персоналізоване навчальне середовище, що об’еднуе } \\
\text { викладачів, студентів у інтегровану систему, призначену } \\
\text { для організації та управління електронним та } \\
\text { дистанційним навчанням. }\end{array}$ \\
\hline Microsoft Teams, Webinar, Zoom, Skype для бізнесу & сервіси для проведення онлайн конференцій. \\
\hline $\begin{array}{l}\text { Slack, Skype, Microsoft Office Outlook, Facebook, } \\
\text { Telegram та Viber }\end{array}$ & засоби електронного зв'язку та обміну інформацією. \\
\hline $\begin{array}{l}\text { Google Диск, YouTube, Blogger, Google Forms, } \\
\text { Google Caйти, Microsoft Sway }\end{array}$ & $\begin{array}{l}\text { хмарні технології для віддаленої обробки та зберігання } \\
\text { навчальних матеріалів. }\end{array}$ \\
\hline Google Docs, Google Analytics, Google Trends & проведення маркетингових досліджень та їх оцінка. \\
\hline Microsoft Excel i Access, Парус, 1C, SPSS & $\begin{array}{l}\text { облікові та аналітичні програми, що використовуються для } \\
\text { ефективної реалізації управлінської фрункції маркетингу. }\end{array}$ \\
\hline Microsoft Power BI & засіб проведення аналітики. \\
\hline $\begin{array}{l}\text { HohliBuilder, Creately, Piktochart, GoogleCharts, } \\
\text { Vizualize }\end{array}$ & онлайн-сервіси що допомагають створювати інфографріку. \\
\hline Zoho Social, SMMplanner & засоби планування роботи у соціальних мережах. \\
\hline Wix, WordPress & програмне забезпечення для створення сайтів. \\
\hline $\begin{array}{l}\text { MindMap, Mindomo, Stormboard, Realtime } \\
\text { Board, Mural }\end{array}$ & $\begin{array}{l}\text { інструмент розробки ідей, карт проектів та інтерактивного } \\
\text { мозкового штурму. }\end{array}$ \\
\hline
\end{tabular}

Джерело: розробка авторали

він повинен проявити готовність до виконання своєї профресійної діяльності в області маркетингу. При џьому змінюеться роль і вимоги до викладачів. Універсальна підготовка, навики володіння сучасними педагогічними та інформаційними технологіями є необхідними для роботи викладачів дистанційних курсів.

Процес підготовки фрахівців 3 використанням інформаційних технологій представлений у вигляді моделі, яка передбачає послідовність у розширенні спектру володіння студентом засобами IT та набуття нового досвіду (рис. 1). Професійна підготовка майбутніх фрахівців 3 використанням сучасних інформаційних технологій має здійснюватися з урахуванням вітчизняного та зарубіжного досвіду. Основою для цього має бути оновлений зміст та форма організації навчального процесу відповідно до міжнародних стандартів. IT рекомендовано використовувати на усіх етапах процесу навчання: при організації навчального процесу, викладанні фрахових дисциплін, перевірки засвоєння матеріалу, причому для студента IT виконують різні функції: викладача (джерело інформації, тренажер, наочний посібник, засіб діагностування освоєння матеріалу), інструментального засобу (інструмент створення документів, графічний редактор, засіб обчислення та моделювання), об'єкту навчання, згуртованого колективу, ігрового середовища.

Інтеграція інформаційних технологій у навчальний процес надає змогу користуватись їх унікальними можливостями, які створюють основу для підвищення інтенсивності навчального процесу та підготовки методичних розробок, спрямованих на розвиток особистості студента (рис. 2).

Перевагою використання інформаційних технологій є те, що ефективне впровадження у навчальний процес дає можливість вирішити наступні завдання:

- розширення можливостей для викладачів щодо використання засобів та інструментів для передачі знань;
- вдосконалення інформаційної культури, спрямованої на формування здібностей здійснювати аналіз інформації (за рахунок використання пакетів прикладних програм);

- формування навичок вирішення організаційних та процедурних питань, тобто здібностей приймати управлінські рішення в умовах складної або позаштатної ситуації (за рахунок застосування комп'ютерних розвиваючих ігор);

- підвищення якості навчального процесу;

- особистісний розвиток студента, підготовка до профресійної діяльності;

- покращення іміджу навчального закладу та залучення споживачів.

Важливою перевагою використання інфрормаційних технологій в освіті е індивідуалізація освітніх процесів. Однак якщо здійснювати загальну індивідуалізацію навчання на основі IT, не піклуючись про розвиток колективних за своєю формою і змістом навчальних занять, в ході яких реалізуються можливості діалогового спілкування і взаємодії, то можна втратити можливість сорормувати мислення студентів. Крім того, виникає небезпека зменшення соціальних контактів, і з'являеться небезпека розвитку індивідуалізму у виробничому та суспільному житті.

Особливу увагу при використанні IT необхідно звернути на шкідливий вплив на здоров'я, особливо на зір. 3 цього випливае, що, прописуючи методику застосування IT, необхідно обмежити час контакту користувача 3 комп'ютером. Також існує небезпека перетворення IT в інструмент, без якого студент стає безпорадним. Кількість студентів, які намагаються знайти потрібну інформащію в мережі Інтернет і при џьому не вміють працювати 3 книгами, 3 довідниками, підручниками в бібліотеці, швидко збільшуеться. Тому необхідно організовувати процес навчання так, щоб показати студентам роль їх власних знань. Для запобігання відриву від реальності при роботі з комп'ютерною симулящією, потрібно звертати увагу на відмінність комп'ютерною моделлю 


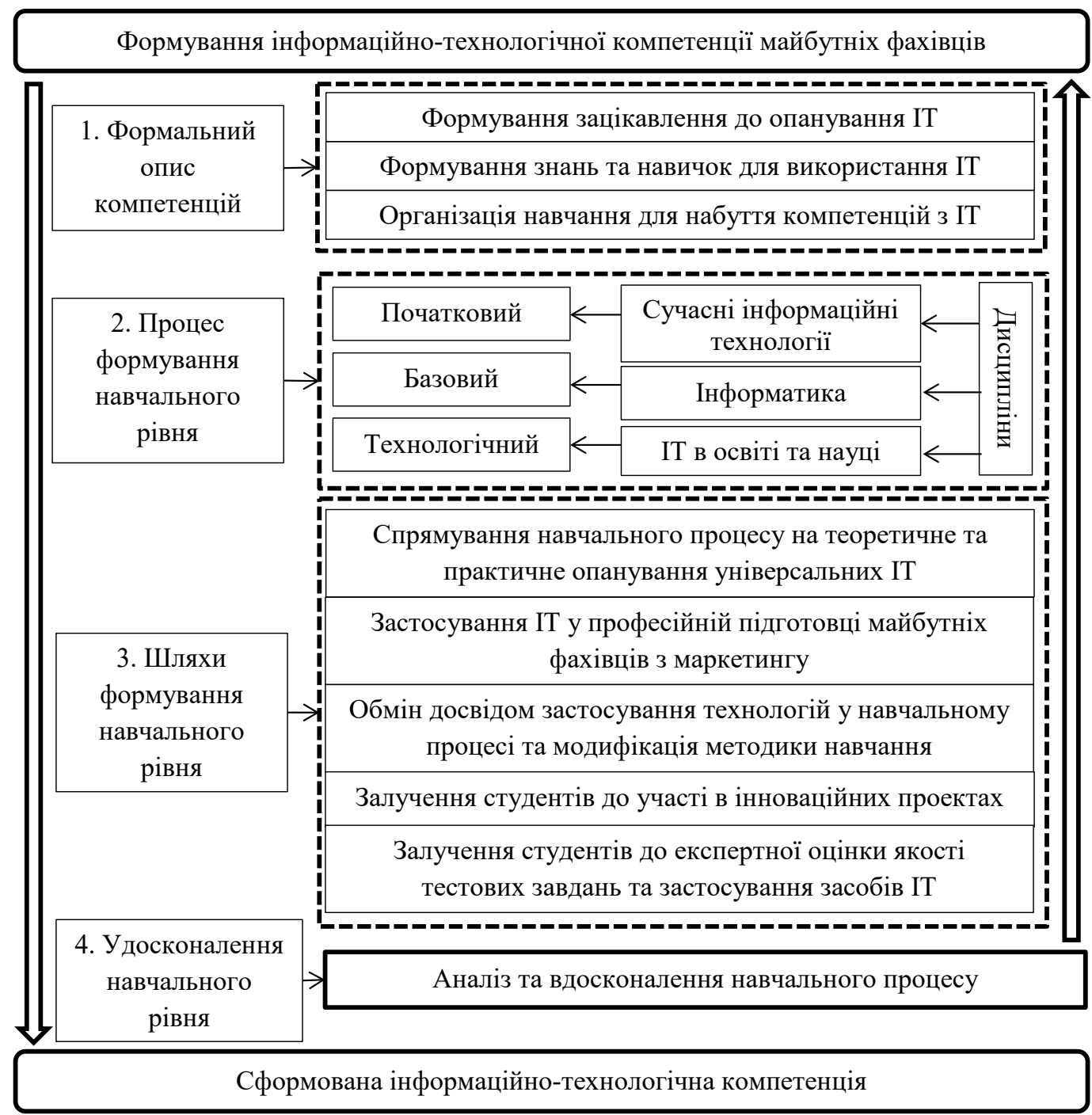

Рис. 1. Модель підготовки фахівців з маркетингу з використанням інформаційних технологій

Джерело: розробка авторами за джерелом [5-6]

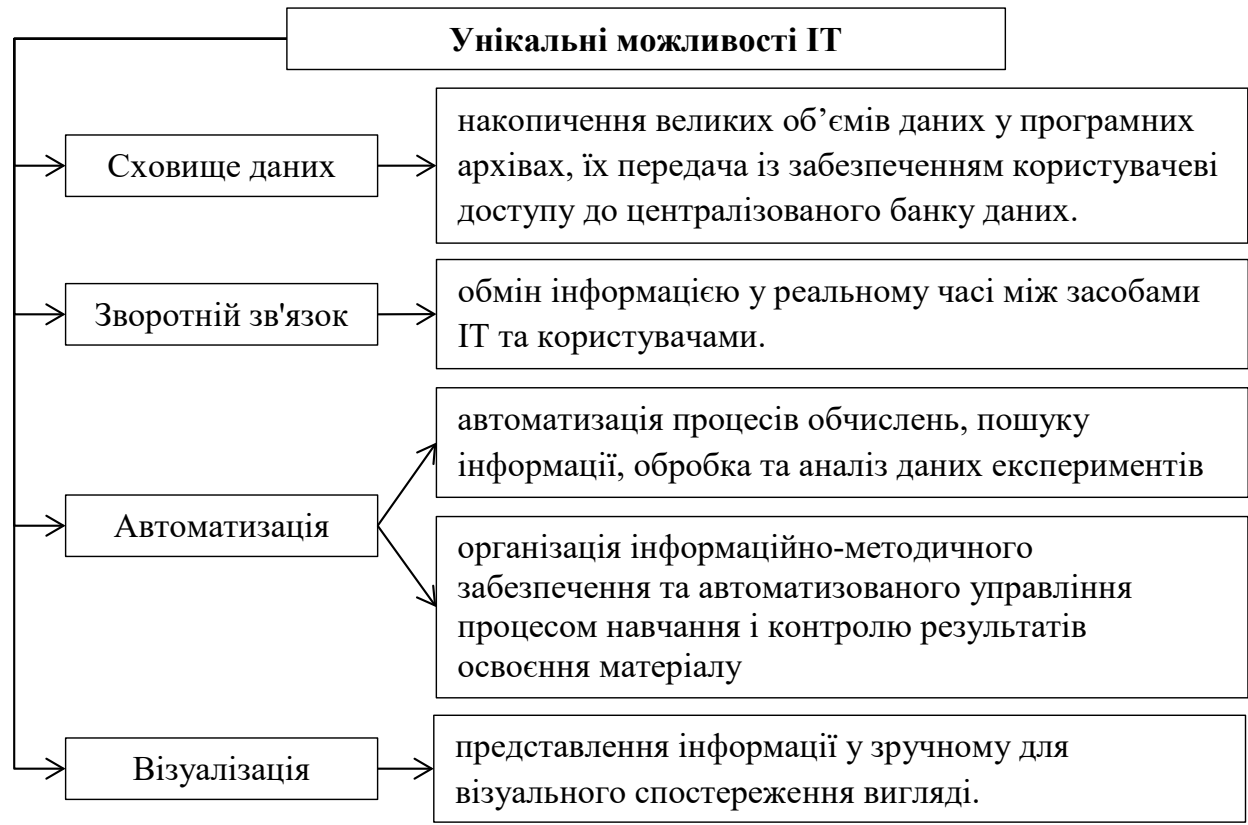

Рис. 2. Унікальні можливості використання інформаційних технологій 
та реальним досвідом, показувати обмеженість моделей з одного боку, та їх можливості з іншого.

Висновки. Отже, нові освітні стандарти та програми мають враховувати вимоги бізнесу до якості підготовки майбутніх маркетологів. У зв'язку з чим виникае необхідність підбору інформаційних технологій, що дозволяють підвищити пізнавальну активність студентів за рахунок різноманітних видів інформації та мають активно застосовуються на всіх етапах і у всіх формах навчання. Особливу роль вони відігра- ють в організащії дистанщійного навчання. Застосування інформаційних технологій у профресійній підготовці фрахівців 3 маркетингу може дати еdрект значного поглиблення знань при розумному співвідношенні традиційних методик навчання та методик, що Ірунтуються на застосуванні IT. У зв'язку з цим виникає необхідність підбору конкретних технологій і методів активного навчання майбутніх фрахівців з використанням IT, що є перспективним напрямком подальших досліджень.

\section{Список літератури:}

1. Кобилянська I.M., Савчук O.I. Інформаційні технології в процесі підготовки фрахівців. 2017. URL: https://conferences.vntu.edu.ua/index.php/itpf/2017/paper/download/3302/2780 (дата звернення: 20.12.2020).

2. Волков Ю.А., Шарлай А.С. Применение современных информационных технологий в образовательном процессе. Специальная техника и технология транспорта. 2019. С. 248-252.

3. Голуб Т.В., Дядичев В.В. Прикладные аспекты применения информационных технологий в учебном процессе высших учебных заведений. Инфбормаиионные систель и технологии в моделировании и управлении. 2019. C. 269-273.

4. Журавлева Е.А. Профессиональное становление будущего маркетолога в современной системе высшего образования. Вестник ЛНУ имени Тараса Шевченко. 2017. № 1(3). С. 66-70.

5. Пасека М.С. Використання інформаційних технологій для професійної підготовки фахівців у галузі педагогіки. Науковий вісник НЛТУ України. 2015. Випуск 25.5. С. 357-362.

6. Андреев В.Н., Горшкова Е.Е., Грешных А.А. Применение информационных технологий при организации образовательного процесса. Научно-аналитический журнал "Вестник Санкт-Петербургского университета Государственной противопожарной службы МЧС России». 2017. С. 139-142.

7. Игнатьев С.А., Терехова М.А., Вахидова К.Л., Тазуева Ж.М. Применение современных информационных технологий в образовании: перспективы, цели и задачи : Материалы I научно-практической конференции «Миллионщиков-2018» (30-31 мая 2018, г. Грозный), Чеченская Республика, г. Грозный : ФГУП «Издательско-полиграфический комплекс «Грозненский рабочий», 2018. С. 83-94.

\section{References:}

1. Kobylyans'ka I.M., Savchuk O.I. (2017) Informatsiyni tekhnolohiyi v protsesi pidhotovky fakhivtsiv [Information technologies in the process of training specialists]. Available at: https://conferences.vntu.edu.ua/index.php/ itpf/2017/paper/download/3302/2780 (accessed 20 December 2020).

2. Volkov Yu.A., Sharlay A.S. (2019) Primenenie sovremennykh informatsionnykh tekhnologiy v obrazovatel'nom protsesse [Application of modern information technologies in the educational process]. Special equipment and technology of transport, pp. 248-252.

3. Golub T.V., Dyadichev V.V. (2019) Prikladnye aspekty primeneniya informatsionnykh tekhnologiy v uchebnom protsesse vysshikh uchebnykh zavedeniy [Applied aspects of the use of information technology in the educational process of higher educational institutions]. Information systems and technologies in modeling and management, pp. 269-273.

4. Zhuravleva E.A. (2017) Professional'noe stanovlenie budushchego marketologa v sovremennoy sisteme vysshego obrazovaniya [Professional development of the future marketer in the modern higher education system]. Bulletin of LNU named after Taras Shevchenko, vol. 1, no. 3, pp. 66-70.

5. Pasyeka M.S. (2015) Vykorystannya informatsiynykh tekhnolohiy dlya profesiynoyi pidhotovky fakhivtsiv u haluzi pedahohiky [Use of information technologies for professional training of specialists in the field of pedagogy]. Scientific Bulletin of NLTU of Ukraine, vol. 25.5, pp. 357-362.

6. Andreev V.N., Gorshkova E.E., Greshnykh A.A. (2017) Primenenie informatsionnykh tekhnologiy pri organizatsii obrazovatel'nogo protsessa [The use of information technology at the organization of the educational process]. Scientific and analytical journal "Bulletin of the St. Petersburg University of the State Fire Service of the EMERCOM of Russia", pp. 139-142.

7. Ignat'ev S.A., Terekhova M.A., Vakhidova K.L., Tazueva Zh.M. (2018) Primenenie sovremennykh informatsionnykh tekhnologiy $\mathrm{v}$ obrazovanii: perspektivy, tseli $\mathrm{i}$ zadachi [Application of modern information technologies in education: prospects, goals and objectives]: Proceedings of the I nauchno-prakticheskaya konferentsiya «Millionshchikov-2018» (Chechen Republic, Grozny, May 30-31, 2018), Grozny: Federal State Unitary Enterprise "Publishing and Printing Complex" Grozny Rabochy", pp. 83-94. 